\title{
Thalassobaculum salexigens sp. nov., a new member of the family Rhodospirillaceae from the NW Mediterranean Sea, and emended description of the genus Thalassobaculum
}

\author{
Laurent Urios ${ }^{1}$, Valérie Michotey ${ }^{2}$, Laurent Intertaglia ${ }^{1}$, Françoise Lesongeur $^{3}$ and Philippe Lebaron $^{1, ~ *}$ \\ ${ }^{1}$ UPMC Univ Paris 6, Laboratoire ARAGO, UMR 7621, Observatoire Océanologique, F-66651 \\ Banyuls/mer, France \\ ${ }^{2}$ Laboratoire de Microbiologie, de Géochimie et d'Ecologie Marines, CNRS-UMR 6117, Centre \\ d'Océanologie de Marseille, Campus de Luminy, Case 901, 13288 Marseille Cedex 9, France \\ ${ }^{3}$ Laboratoire de Microbiologie des Environnements Extrêmes, UMR 6197, IFREMER, Centre de \\ Brest, BP 70, 29280 Plouzané, France \\ *: Corresponding author : P. Lebaron, email address : lebaron@obs-banyuls.fr
}

\begin{abstract}
:
A novel Gram-negative bacteria, named CZ41_10a', was isolated from coastal surface waters of the north-western Mediterranean Sea. Cells were motile, pleomorphic rods, $1.6 \mu \mathrm{m}$ long and $0.7 \mu \mathrm{m}$ wide and formed cream colonies on marine agar medium. The $G+C$ content of the genomic DNA was 65 mol\%. Phylogenetic analysis of 16S rRNA gene sequences placed the new isolate in the genus Thalassobaculum, a member of the family Rhodospirillaceae, class Alphaproteobacteria. Unlike Thalassobaculum litoreum CL-GR58 ${ }^{\top}$, its closest relative, strain CZ41_10a ${ }^{\top}$ was unable to grow anaerobically and did not exhibit nitrate reductase activity. On the basis of DNA-DNA hybridization, fatty acid content and physiological and biochemical characteristics, this isolate represents a novel species for which the name Thalassobaculum salexigens $\mathrm{sp}$. nov. is proposed. The type strain is CZ41_10a ${ }^{\top}\left(=D S M \quad 19539^{\top}=\right.$ CIP $109064^{\top}=$ MOLA $\left.84^{\top}\right)$. An emended description of the genus Thalassobaculum is also given.
\end{abstract}


Bacteria performing the many steps of the nitrogen cycle are of great interest for agricultural and environmental questions. Among these organisms, members of the genus Azospirillum are well studied because of their association with plants and their ability to fix nitrogen. Eleven species have already been described. Three strains, close to Azospirillum species, were isolated from surface waters in the Mediterranean Sea. As they were putative new taxa, an investigation into their taxonomy and characteristics were performed. Their taxonomic position and their environmental origin led to hypotheses of their possible involvement in the nitrogen cycle, as the marine nitrogen cycle and nitrogen flows between oceans and the atmosphere are key processes (Capone \& Knapp, 2007). Of the three strains, two have been recently described as members of a novel genus, Nisaea (Urios et al., 2008). Denitrification genes nirK and nosZ were found in Nisaea denitrificans whereas Nisaea nitritireducens possessed only nirK. The ability to denitrify was confirmed by culturing methods. The third strain, named CZ41_10a ${ }^{\mathrm{T}}$, was not able to denitrify and did not possessed nirK nor nosZ. CZ41_10a was phylogenetically placed between the genera Nisaea and Azospirillum. Recently, Thalassobaculum litoreum, a new species of a new genus belonging to the family Rhodospirillaceae was published (Zhang et al., 2008). The type strain shared 99\% 16S rDNA gene sequence similarity with strain CZ41_10a ${ }^{\mathrm{T}}$ but DNA-DNA hybridization, G+C content, fatty acid composition, physiological and biochemical characteristics showed numerous and important differences between Thalassobaculum litoreum and strain CZ41_10a ${ }^{\mathrm{T}}$. In this paper these different properties are provided and demonstrate $C Z 41 \_10 \mathrm{a}^{\mathrm{T}}$ represents a new species of the genus Thalassobaculum.

Samples were collected in February 2004 at the SOLA station located in the bay of Banyulssur-Mer $\left(42^{\circ} 29^{\prime} \mathrm{N} 3^{\circ} 08^{\prime} \mathrm{E}\right)$ at $3 \mathrm{~m}$ depth. Subsamples were spread on Nutrient Agar plates (BIO-RAD, Marnes-la-Coquette, France) made with filtered sea water, and incubated at $25^{\circ} \mathrm{C}$ 
for 2 weeks. Colonies were picked and purified by 3 subcultures. Among these colonies, an isolate forming cream coloured colonies was obtained and referenced as strain CZ41_10a ${ }^{\mathrm{T}}$.

Microscope observations (Olympus AX70) showed that cells from isolate CZ41_10a ${ }^{\mathrm{T}}$ were motile rods, approximately $1.6 \pm 0.3 \mu \mathrm{m}$ long and $0.7 \pm 0.2 \mu \mathrm{m}$ wide. Cells were negatively stained for transmission electron microscopy (Raguénès et al., 1997). A single polar flagellum was observed. The Ryu KOH reaction (Powers, 1995) led to an immediate cell lysis that was confirmed by microscopy (Olympus AX70). This positive reaction indicated that the cells were Gram-negative.

The isolate was grown in marine broth medium (MB 2216, Difco, Detroit, Mich, USA). For determining its salinity range, marine broth medium was prepared according to the composition provided by the manufacturer but with different $\mathrm{NaCl}$ concentrations. For the $\mathrm{pH}$ range, MES, PIPES, AMPSO or MOPS (Sigma, St. Louis, MO, USA) was added to marine broth medium to achieve different $\mathrm{pH}$ values. Cultures were incubated at $30^{\circ} \mathrm{C}$ under aerobic conditions. Methods for the determination of growth parameters were as reported by Wery et al. (2001b). Growth was observed at $15-37^{\circ} \mathrm{C}$ with an optimum temperature of $30^{\circ} \mathrm{C}$ (Supplementary Fig. S2). The strain grew at sea salts concentrations ranging from 10 to $80 \mathrm{~g} \mathrm{l}^{-}$ ${ }^{1}\left(7\right.$ to $\left.54 \mathrm{~g} \mathrm{l}^{-1} \mathrm{NaCl}\right)$ and an optimum concentration could be defined between 50 and $60 \mathrm{~g} \mathrm{l}^{-1}$ (34 to $40 \mathrm{~g} \mathrm{l}^{-1} \mathrm{NaCl}$ ) (Supplementary Fig. S2). No significant growth was observed without sea salts. Growth occured over a range $\mathrm{pH} 5.0$ - 10.0 with a clear optimum at $\mathrm{pH}$ 8.0. Growth decreased by $50 \%$ at $\mathrm{pH} 9.0$, compared to the value obtained at $\mathrm{pH} 8.0$ whereas a relative decrease of only $22 \%$ was observed at pH 6.0 (Supplementary Fig. S2).

3 The strain's ability to use different substrates was investigated using Biolog GN2 MicroPlates 4 (Tang et al., 1998) according to the manufacturer's instructions except for the incubation 
time: measurements were made hourly during 24h. Positive reactions were observed for arabitol, erythritol, fructose, fucose, glucose, lactose, lactulose, mannitol, $\gamma$-hydroxybutyrate and propionate (Table 1). Weak positive reactions were noted for adonitol, mannose, sorbitol and $\beta$-hydroxybutyrate (Table 1).

Enzymatic activities of the strain were investigated using the API ZYM system (bioMérieux) according to the manufacturer's instructions. Leucine arylamidase and valine arylamidase exhibited positive reactions and a weak signal was observed for acid phosphatase (Table 1).

Fatty acid methyl esters composition was carried out by the Identification Service of the DSMZ (DSMZ, Braunschweig, Germany). The fatty acid compositions for strain CZ41_10a ${ }^{\mathrm{T}}$ and related bacteria are shown in Table 2 . The large amounts of $18: 1 \omega 7 \mathrm{c}$ and, to some extent,

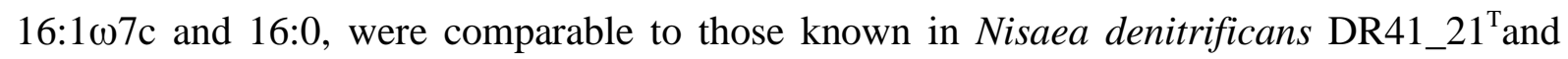
Thalassobaculum litoreum CL-GR58 ${ }^{\mathrm{T}}$. In contrast, 17:1 $\omega 6 \mathrm{c}, 17: 1 \omega 8 \mathrm{c}, 11$ methyl 18:1 $\omega 7 \mathrm{c}$ and 17:0-3OH were not found in Nisaea denitrificans DR41_21 $1^{\mathrm{T}}$ and 17:0 was 16-fold more represented than in Nisaea denitrificans DR41_21 $1^{\mathrm{T}}$ and Nisaea nitritireducens DR41_18 ${ }^{\mathrm{T}}$. 20:1w9c and the unknown fatty acid ECL 18.814 found in Thalassobaculum litoreum CLGR58 ${ }^{\mathrm{T}}$ were not detected in strain CZ41_10a ${ }^{\mathrm{T}}$. The level of 19:0 cyclo $\omega 8 \mathrm{c}$ in CZ41_10a ${ }^{\mathrm{T}}$ is comparable to that of Nisaea nitritireducens DR41_18 ${ }^{\mathrm{T}}$ but 6-fold less than found in Thalassobaculum litoreum CL-GR58 ${ }^{\mathrm{T}} .18: 1 \omega 7 \mathrm{c}$ and $16: 1 \omega 7 \mathrm{c} / \mathrm{i}-15-2 \mathrm{OH}$ contents found in strain CZ41_10a ${ }^{\mathrm{T}}$ are higher than in Nisaea strains but lower than in Thalassobaculum litoreum CL-GR58 ${ }^{\mathrm{T}}$. Among the 4 major fatty acids found in strain CZ41_10a ${ }^{\mathrm{T}}, 3$ have significantly higher contents than in Thalassobaculum litoreum $(18: 1 \omega 7 \mathrm{c}, 17: 0$ and $16: 1 \omega 7 \mathrm{c}$ / $\mathrm{i}-15-2 \mathrm{OH}$ ) and 16:0 is clearly less represented than in Thalassobaculum litoreum CL-GR58 ${ }^{\mathrm{T}}$ but has the same value than in Nisaea strains. 
109 Analysis of respiratory quinones was carried out by the Identification Service of the DSMZ

110 Identification Service (DSMZ, Braunschweig, Germany). Strain CZ41_10a ${ }^{\mathrm{T}}$ has mainly

111 ubiquinone-10 (Q 10).

112

113 Genomic DNA was extracted as described by Wery et al. (2001a). The G+C content was

114 determined by thermal denaturation using the method of Marmur \& Doty (1962) and 115 conditions reported by Raguénès et al. (1997). The G+C content of the genomic DNA of 116 strain CZ41_10a $\mathrm{a}^{\mathrm{T}}$ was $65 \mathrm{~mol} \%$. The $16 \mathrm{~S}$ rRNA gene was amplified and sequenced as 117 described by Agogué et al. (2005). The sequence was analysed as described by Urios et al. 118 (2006). Strain CZ41_10a ${ }^{\mathrm{T}}$ was phylogenetically affiliated to the family Rhodospirillaceae in 119 the phylum Proteobacteria (Fig. 1). The nearest relatives were Thalassobaculum litoreum DSM $18839^{\mathrm{T}}$ (similarity value of 99\%), Nisaea nitritireducens (= DSM 19540 ${ }^{\mathrm{T}}$ ) (similarity value of 94\%) and Nisaea denitrificans (= DSM 18348 ${ }^{\mathrm{T}}$ (similarity value of $93 \%$ ).

122 Consequently, DNA-DNA hybridization was performed by the DSMZ Identification Service 123 (DSMZ, Braunschweig, Germany). The results indicated $66 \% \pm 1 \%$ of DNA-DNA similarity 124 between Thalassobaculum litoreum DSM $18839^{\mathrm{T}}$ and strain CZ41_10a .

126 Because of the metabolic capabilities of the closest relatives of strain CZ41_10a ${ }^{\mathrm{T}}$, participation 127 to the nitrogen cycle was investigated. To amplify narG, nirS, nirK, nosZ, nifH and AmoA 128 genes, published primers were used: na3F-narG5'R for narG (Goregues et al., 2005), cd3F129 cd4R for nirS (Michotey et al., 2000), nirKCF-nirKCR for nirK (Goregues et al., 2005), 130 nosZ1211F-nosZ1897R for nosZ (Rosch et al., 2002), nifHF-nifHR for nifH (Zehr \& 131 McReynolds, 1989), AmoA-1F-AmoA-2R for AmoA (Rotthauwe et al., 1997). PCR 132 amplification was carried out as previously described (Urios et al., 2008). Among the tested 133 genes, none were successfully amplified by PCR. Anaerobic growth experiments were 
134 performed as described by Urios et al. (2008). Unlike Nisaea denitrificans and

135 Thalassobaculum litoreum CL-GR58 ${ }^{\mathrm{T}}$ (Zhang et al., 2008), no growth was observed.

136

137 Some characteristics of strain CZ41_10a ${ }^{\mathrm{T}}$ are quite similar to those of Thalassobaculum

138 litoreum CL-GR58 ${ }^{\mathrm{T}}$, its nearest relative such as motile cells with a single polar flagellum,

139 optimal growth temperature and $\mathrm{pH}$, ubiquinone Q-10 and some of the major fatty acids.

140 Nevertheless, strain CZ41_10a ${ }^{\mathrm{T}}$ has a 12-fold higher salinity optimum and an inability to

141 grow without sea salts, a wider $\mathrm{pH}$ growth range, a 3\% lower $\mathrm{G}+\mathrm{C}$ content, 6 out of 8

142 different API ZYM positive reactions and a fully different substrates profile. Unlike

143 Thalassobaculum litoreum CL-GR58 ${ }^{\mathrm{T}}$, strain CZ41_10a ${ }^{\mathrm{T}}$ was not able to grow anaerobically,

144 nor did it exhibit nitrate reductase activity. Finally, DNA-DNA hybridization results indicated

$14566 \%$ of DNA-DNA similarity.

146

147 Based on phenotypic and genotypic differences between strain CZ41_10a ${ }^{\mathrm{T}}$ and its nearest

148 described relatives, we propose that strain CZ41_10a ${ }^{\mathrm{T}}$ should be assigned to a novel species

149 belonging to the genus Thalassobaculum. Due to the sea salts requirement for the growth of

152 Description of Thalassobaculum salexigens sp. nov.

153 Thalassobaculum salexigens (sa.lex'i.gens. L. n. sal salis salt, sea water; L. v. exigo to 154 demand; N.L. part. adj. salexigens sea water-demanding). The strain forms cream colonies on 155 Marine Agar medium. The $\mathrm{G}+\mathrm{C}$ content of strain $\mathrm{CZ41} \_10 \mathrm{a}^{\mathrm{T}}$ is $65 \%$. Ubiquinone is 156 ubiquinone Q-10. Major fatty acids are: 18:1 $\omega 7 \mathrm{c}, 17: 0,16: 0$ and 16:1 $17 \mathrm{c}$. Growth occurs at $15715-37^{\circ} \mathrm{C}$ (optimum $30^{\circ} \mathrm{C}$ ), at $\mathrm{pH} 5.0-10.0$ (optimum 8.0) and salinity range of $7-54 \mathrm{~g} \mathrm{l}^{-1}$

158 (optimum $34-40 \mathrm{~g} \mathrm{l}^{-1}$ ). Catalase and oxidase tests were positive. Positive reactions with 
159 Biolog GN2 plates were obtained for arabitol, erythritol, fructose, fucose, glucose, lactose,

160 lactulose, mannitol, $\gamma$-hydroxybutyrate and propionate. API ZYM positive reactions for

161 enzymatic activities were obtained for leucine arylamidase and valine arylamidase. The type

162 strain CZ41_10a ${ }^{\mathrm{T}}\left(=\mathrm{DSMZ} 19539^{\mathrm{T}}=\right.$ CIP $109064^{\mathrm{T}}=$ MOLA 84 $\left.4^{\mathrm{T}}\right)$ was isolated from the

163 water column in the bay of Banyuls-sur-Mer (42²9’ N $\left.3^{\circ} 08^{\prime} \mathrm{E}\right)$.

164

165 Emended description of the genus Thalassobaculum Zhang et al. 2008

166 The description of the genus Thalassobaculum is as given by Zhang et al. (2008) with the

167 following amendments. Some of the strains are facultative anaerobes. The major fatty acids

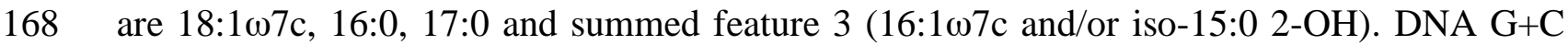

169 content is $65-68 \mathrm{~mol} \%$.

170

171 Acknowledgements.

172 This work was supported by the Equipe Mixte de Recherche linking the University Pierre et

173 Marie Curie and the Centre National de la Recherche Scientifique to the Pierre Fabre

174 Laboratories. The project was also partly funded by the EU project BASICS (EVK3-CT-

175 2002-00018) and by a grant from the Institut Français de la Biodiversité (IFB-GICC, Paris,

176 France). The project was also carried out in the frame of the MarBEF Network of Excellence

177 'Marine Biodiversity and Ecosystem Functioning' which is funded in the Community's Sixth

178 Framework Programme (contract no. GOCECT-2003-505446). This publication is 179 contribution number MPS-09012 of MarBEF. 


\section{References}

182

183

184

185

186

187

188

189

190

191

192

193

194

195

196

197

198

199

200

201

202

203

204

205

206

207

208

209

210

211

212

213

214

215

216

217

218

219

220

221

222

223

224

Agogué, H., Casamayor, E. O., Bourrain, M., Obernosterer, I., Joux, F., Herndl, G. J. \& Lebaron, P. (2005). A survey on bacteria inhabiting the sea surface microlayer of coastal ecosystems. FEMS Microbiol Ecol 54, 269-280.

Capone, D. G. \& Knapp, N. (2007). A marine nitrogen cycle fix ? Nature 445, 159-160.

Goregues, C. M., Michotey, V. D. \& Bonin, P. C. (2005). Molecular, biochemical, and physiological approaches for understanding the ecology of denitrification. Microb Ecol 49, 198-208.

Marmur, J. \& Doty, P. (1962). Determination of the base composition of desoxyribonucleic acid from its thermal denaturation temperature. J Mol Biol 5, 109-118.

Michotey, V., Mejean, V. \& Bonin, P. (2000). Comparison of methods for quantification of cytochrome cd(1)-denitrifying bacteria in environmental marine samples. Appl Environ Microbiol 66, 1564-1571.

Powers, E. (1995). Efficacy of the Ryu nonstaining KOH technique for rapidly determinig Gram reactions of food-borne and waterborne bacteria and yeasts. Appl Environ Microbiol 61, 3756-3758.

Raguénès, G., Christen, R., Guézennec, J., Pignet, P. \& Barbier, G. (1997). Vibrio diabolicus sp. nov., a new polysaccharidic-secreting organism isolated from a deep-sea hydrothermal vent polychete annelid, Alvinella pompejana. Int J Syst Bacteriol 47, 989-995.

Rosch, C., Mergel, A. \& Bothe, H. (2002). Biodiversity of denitrifying and dinitrogen-fixing bacteria in an acid forest soil. Appl Environ Microbiol 68, 3818-3829.

Rotthauwe, J. H., Witzel, K. P. \& Liesack, W. (1997). The ammonia monooxygenase structural gene amoA as a functional marker: molecular fine-scale analysis of natural ammonia-oxidizing populations. Appl Environ Microbiol 63, 4704-4712.

Tang, Y., W. Ellis, N. M., Hopkins, M. K., Smith, D. H., Dodge, D. E. \& Persing, D. H. (1998). Comparison of phenotypic and genotypic techniques for identification of unusual aerobic pathogenic gram-negative bacilli. J Clin Microbiol 36, 3674-3679

Urios, L., Agogué, H., Lesongeur, F., Stackebrandt, E. \& Lebaron, P. (2006). Balneola vulgaris gen. nov., sp. nov., a member of the phylum Bacteroidetes from the north-western Mediterranean Sea. Int J Syst Evol Microbiol 56, 1883-1887.

Urios, L., Michotey, V., Intertaglia, L., Lesongeur, F. \& Lebaron, P. (2008). Nisaea denitrificans gen. nov., sp. nov. and Nisaea nitritireducens sp. nov., two new members of the Alphaproteobacteria from the Mediterranean Sea. Int J Syst Evol Microbiol 58, 2336-2341.

Wery, N., Lesongeur, F., Pignet, P., Derennes, V., Cambon-Bonavita, M., Godfroy, A. \& Barbier, G. (2001a). Marinitoga camini gen. nov., sp. nov., a rod-shaped bacterium 
228 belonging to the order Thermotogales, isolated from a deep-sea hydrothermal vent. Int J Syst 229 Evol Microbiol 51, 495-504.

231 Wery, N., Moricet, J., Cueff, V., Jean, J., Pignet, P., Lesongeur, F., Cambon-Bonavita, 232 M. \& Barbier, G. (2001b). Caloranaerobacter azorensis gen. nov., sp. nov., an anaerobic 233 thermophilic bacterium isolated from a deep-sea hydrothermal vent. Int J Syst Evol Microbiol 234 51, 1789-1796.

Zhang, G. I., Hwang, C. Y. \& Cho, B. C. (2008). Thalassobaculum litoreum gen. nov., sp. 237 nov., a member of the family Rhodospirillaceae isolated from coastal seawater. Int J Syst 238 Evol Microbiol 58, 479-485.

Zehr, J. P. \& McReynolds, L. A. (1989). Use of degenerate oligonucleotides for amplification of the nif $\mathrm{H}$ gene from the marine cyanobacterium Trichodesmium thiebautii. Appl Environ Microbiol 55, 2522-2526. 
246 TABLE 1. Characteristics distinguishing strain CZ41_10a ${ }^{\mathrm{T}}$ from related species.

247 Strains: 1, Nisaea denitrificans DR41_21 ${ }^{\mathrm{T}}$; 2, Nisaea nitritireducens DR41_18 ${ }^{\mathrm{T}}$; 3, strain 248 CZ41_10a ${ }^{\mathrm{T}}$; 4, Thalassobaculum litoreum CL-GR58 ${ }^{\mathrm{T}}$ +, positive; -, negative; w, weakly 249 positive.

\begin{tabular}{|c|c|c|c|c|}
\hline & 1 & 2 & 3 & 4 \\
\hline $\mathrm{G}+\mathrm{C}$ content $(\mathrm{mol} \%)$ & 60 & 60 & 65 & 68 \\
\hline \multicolumn{5}{|l|}{ Growth conditions } \\
\hline température range (optimum) ${ }^{\circ} \mathrm{C}$ & $15-(30)-44$ & $15-(30)-44$ & $15-(30)-37$ & $10-(30-35)-35$ \\
\hline salinity range (optimum) (g.L $\left.\mathrm{L}^{-1}\right)$ & $0-(20)-60$ & $0-(20)-60$ & $7-(34-40)-54$ & $1-(2-4)-10$ \\
\hline pH range (optimum) & $5-(6)-9$ & $5-(6)-9$ & $5-(8)-10$ & $7-(8)-9$ \\
\hline \multicolumn{5}{|l|}{ Substrates: } \\
\hline ribose & - & - & - & + \\
\hline arabinose & - & - & - & + \\
\hline fructose & + & + & + & - \\
\hline glucose & + & + & + & - \\
\hline trehalose & $\mathrm{w}$ & $\mathrm{w}$ & - & - \\
\hline lactose & - & - & + & - \\
\hline maltose & - & - & - & ND \\
\hline mannitol & $\mathrm{w}$ & $\mathrm{w}$ & + & - \\
\hline glycerol & $\mathrm{w}$ & $\mathrm{w}$ & - & ND \\
\hline xylitol & $\mathrm{W}$ & $\mathrm{W}$ & - & ND \\
\hline raffinose & + & + & - & - \\
\hline sucrose & - & - & - & + \\
\hline acetate & + & + & - & - \\
\hline$\gamma$-hydroxybutyrate & + & + & + & ND \\
\hline propionate & + & + & + & ND \\
\hline \multicolumn{5}{|l|}{ API ZYM reactions: } \\
\hline alkaline phosphatase & + & + & - & + \\
\hline leucine arylamidase & + & + & + & + \\
\hline valine arylamidase & - & - & + & + \\
\hline acid phosphatase & + & + & $\mathrm{w}$ & + \\
\hline esterase $(\mathrm{C} 4)$ & - & - & - & + \\
\hline naphtol-AS-BI-phosphohydrolase & - & - & - & + \\
\hline$\alpha$ - \& $\beta$-glucosidases & - & - & - & + \\
\hline $\mathrm{N}$-acetyl- $\beta$-glucosaminidase & - & - & - & + \\
\hline
\end{tabular}


252 TABLE 2. Comparison of lipids compositions of strain CZ41_10 ${ }^{\mathrm{T}}$ and related species.

253 Strains: 1, Nisaea denitrificans DR41_21 ${ }^{\mathrm{T}}$; 2, Nisaea nitritireducens DR41_18 $8^{\mathrm{T}}$; 3, strain 254 CZ41_10a ${ }^{\mathrm{T}} ; 4$, Thalassobaculum litoreum $\mathrm{CL}-\mathrm{GR} 58^{\mathrm{T}}$. tr, traces. All strains were grown on 255 MA2216.

\begin{tabular}{|lcccc|}
\hline $16: 03 \mathrm{OH}$ & $\mathbf{1}$ & $\mathbf{2}$ & $\mathbf{3}$ & $\mathbf{4}$ \\
$17: 03 \mathrm{OH}$ & 1.1 & 1.0 & - & - \\
$18: 0-3 \mathrm{OH}$ & - & - & 1.1 & $\operatorname{tr}$ \\
$15: 0$ & - & 1.0 & 1.0 & $\operatorname{tr}$ \\
$16: 0$ & 1.0 & - & 1.7 & 1.5 \\
$17: 0$ & 11.3 & 10.6 & 10.7 & 14.8 \\
$18: 0$ & 1.0 & 1.0 & 16.0 & 12.2 \\
$17: 1 \omega 6 \mathrm{c}$ & - & 1.0 & 1.1 & 2.0 \\
$17: 1 \omega 8 \mathrm{c}$ & - & - & 1.3 & $\operatorname{tr}$ \\
$18: 1 \omega 7 \mathrm{c}$ & - & - & 1.1 & $\operatorname{tr}$ \\
$16: 1 \omega 7 \mathrm{c} / \mathrm{i}-15-2 \mathrm{OH}$ & 69.1 & 67.6 & 55.4 & 48.5 \\
$10-\mathrm{methyl} 19: 0$ & 13.9 & 14.1 & 8.1 & 6.0 \\
11 methyl 18:1 $\omega 7 \mathrm{c}$ & 1.0 & - & - & - \\
$19: 0$ cyclo $\omega 8 \mathrm{c}$ & - & - & 2.1 & 3.0 \\
$20: 1 \omega 9 \mathrm{c}$ & - & 1.8 & 1.0 & 6.3 \\
ECL 18.814 & - & - & - & tr \\
\hline
\end{tabular}



Azospirillum lipoferum ATCC $29707^{1}$, M59061

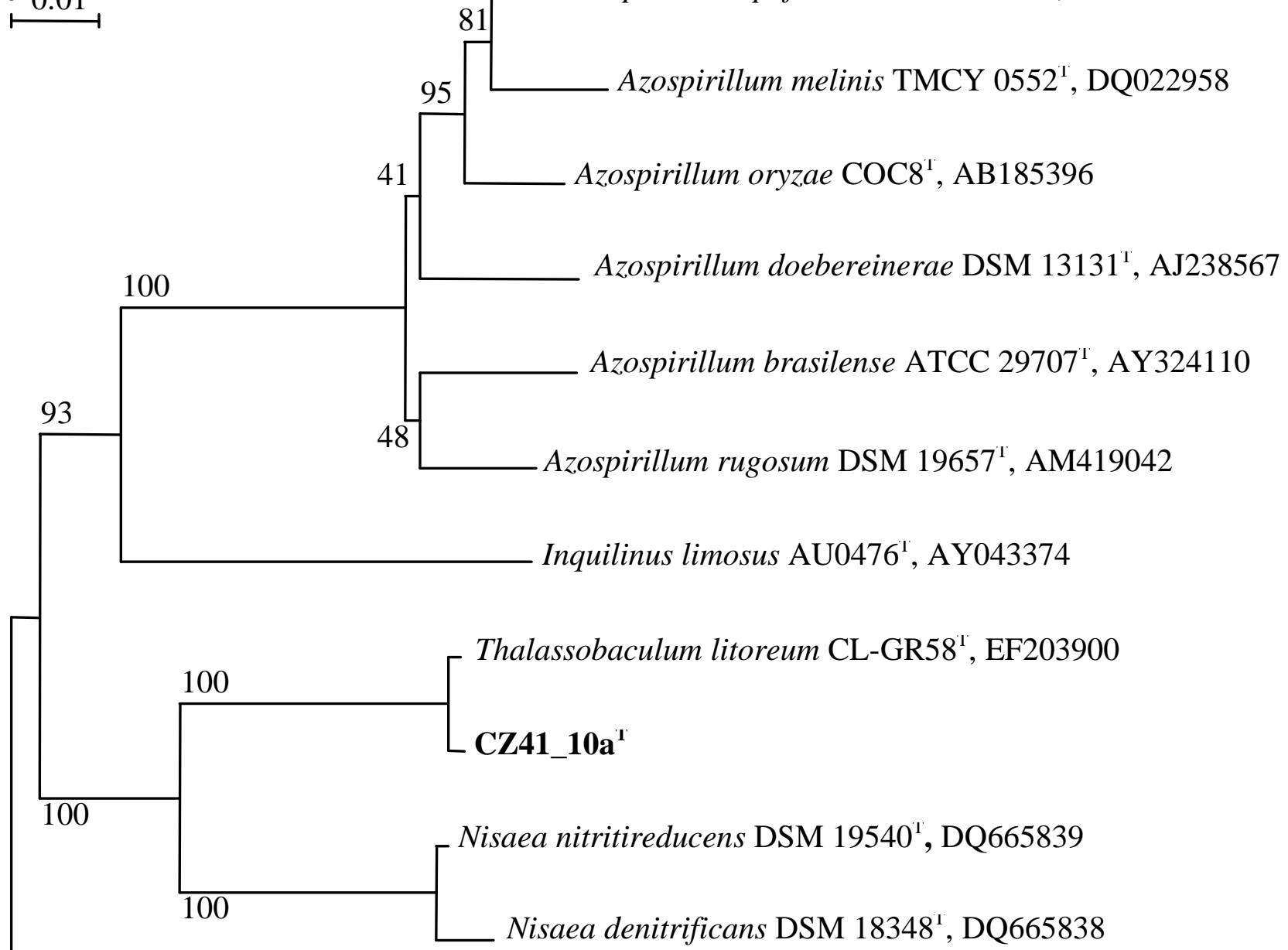
Roseospira marina CE2105' ${ }^{1}$, AJ298879 

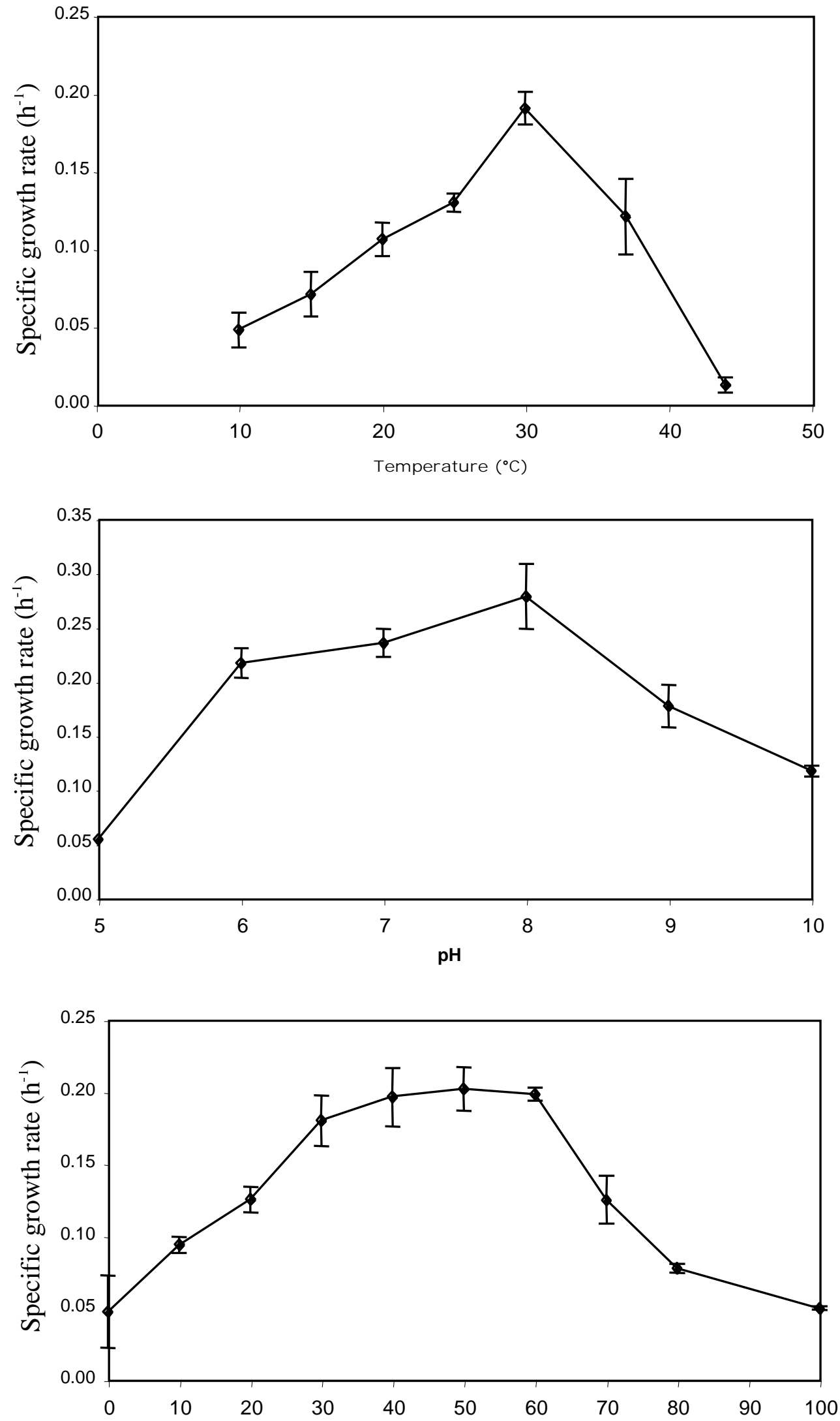

[Sea Salts] $\left(\mathrm{g} \mathrm{I}^{-1}\right)$ 
262 Fig. 1. Phylogenetic tree showing the position of strain CZ41_10a ${ }^{\mathrm{T}}$. Roseospira marina was 263 used as an outgroup. Accession numbers and type strains are indicated. The tree corresponds 264 to an unrooted tree obtained by the neighbor-joining algorithm (Kimura corrections). 265 Bootstrap values are displayed on their relative branches.

269 Fig. S2. Effects of temperature, $\mathrm{pH}$ and $\mathrm{NaCl}$ concentration on the growth of strain 270 CZ41_10a ${ }^{\mathrm{T}}$. 